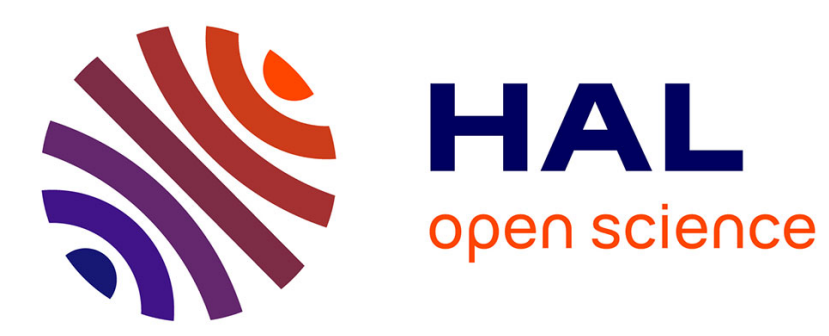

\title{
Isolation of Microorganisms Producing 6-Deoxyhexose-Containing Polysaccharides
}

Marianne Graber, André Morin, Pierre Monsan

\section{To cite this version:}

Marianne Graber, André Morin, Pierre Monsan. Isolation of Microorganisms Producing 6Deoxyhexose-Containing Polysaccharides. Systematic and Applied Microbiology, 1988, 10 (2), pp.200205. 10.1016/S0723-2020(88)80038-9 . hal-01685645

\section{HAL Id: hal-01685645 https://hal.science/hal-01685645}

Submitted on 16 Jan 2018

HAL is a multi-disciplinary open access archive for the deposit and dissemination of scientific research documents, whether they are published or not. The documents may come from teaching and research institutions in France or abroad, or from public or private research centers.
L'archive ouverte pluridisciplinaire HAL, est destinée au dépôt et à la diffusion de documents scientifiques de niveau recherche, publiés ou non, émanant des établissements d'enseignement et de recherche français ou étrangers, des laboratoires publics ou privés. 


\title{
Isolation of Microorganisms Producing 6-Deoxyhexose- Containing Polysaccharides
}

\author{
MARIANNE GRABER-GUBERT, ANDRE MORIN, and PIERRE MONSAN \\ BioEurope 4, impasse Didier Daurat, Z.1. de Montaudran, 31400 Toulouse, France
}

\section{Summary}

A screening of 27 collection strains and 135 strains isolated from carbohydrate rich waste materials permitted the selection of 13 strains which produced more 6-deoxyhexosecontaining polysaccharides than a reference strain: Acinetobacter calcoaceticus BD 413 (ATCC 33304). The most productive strain identified as Klebsiella sp. excreted $1.6 \mathrm{~g}$ of rhamnose per liter of culture medium after improvement of certain culture conditions. The Klebsiella polysaccharide was recovered by precipitation which acetone and hydrolyzed. Rhamnose was separated by chromatography on Dowex $1 \times 4$ in borate buffer. Our study shows that sewage sludge is a good source of polysaccharide producers and that the use of hydro carbon in selective medium and of a high carbon-nitrogen ratio promotes their development.

Key words: Klebsiella sp. - Microbial polysaccharides - Rhamnose - Fucose - Screening

\section{Introduction}

Some microbial polysaccharides have a commercial value due to their gel forming or emulsifying properties, while others represent a source of certain important monosaccharides such as the 6-deoxyhexoses (6dh) rhamnose and fucose (Paul et aJ., 1986). Among the bacterial strains whose polysaccharides' chemical composition is known, about half the strains produce 6dh-containing polysaccharides (Berthelet et al., 1984). Although some of these strains produce up to several $\mathrm{g}$ per litre of $6 \mathrm{dh}$-containing polysaccharide, none but one has been studied with the intention of producing 6dh (Voelskow and Schlingmann, 1984). To our knowledge, no microorganism has been reported to excrete free $6 \mathrm{dh}$ such as rhamnose or fucose. Screening methods for the selection of polysaccharide producing microorganisms taking advantage of resistance to antibiotics (Rubinovitz et al., 1982) or to phages (Martin, 1973) have been described. However no screening for the isolation of microbial strains producing 6dh-containing polysaccharides from samples taken from the environment has been reported. Soils rich in oily deposits (Wang and Schwartz, 1985), or in hydrocarbon wastes (Guerra Santos, 1985\} are favorable for polysaccharide-producing strains. Sewage sludges contain microorganisms producing polysaccharides having $6 \mathrm{dh}$ as main components (Kakii et al., 1986; Rideau and Morfaux, 1976). Habitats containing large 
amounts of carbohydrate waste materials and small amounts of nitrogenous substrates favour polysaccharide production in many microorganisms (Lawson and Sutherland, 1978).

Our study deals with the screening of microbial strains producing rhamnose- or fucosecontaining polysaccharides.

We report the variation in rhamnose yield produced by a Klebsiella sp. strain isolated from sewage sludges as a function of growth conditions.

\section{Materials and Methods}

\section{Screening}

Microbial strains. The following 27 collection strains were purchased from the American Type Culture Collection (ATCC, Rockville, U.S.A.), from the Deutsche Sammlung von Mikroorganismen (DSM, Gottingen, West Germany), from the Institut Pasteur (IP, Paris, France), Central bureau Voor Schimmelcultures

(CBS, Barn, Delft, The Netherlands) and from the National Collection of Industrial Bacteria (NCIB, Aberdeen, Great Britain) Acinetobacter calcoaceticus BD 413 (ATCC 33304), DSM 586IP 64.7, IP 64.8, IP 6632 and IP 6633, Alcaligenes sp. ATCC 31853, Bacillus polymixa Ncrn 11429, Beijerinckia indica NCrn 8849, Beijerinckia mobilis NCrn 9879 and DSM 1720, Corynebacterium insidiosum DSM 20157, Enterobacter sakazakii ATCC 12868, ATCC 29004 and ATCC 29544, Pseudomonas elodea ATCC 31461, Pseudomonas cepacia DSM 50180 and DSM 50181, Rhodotorura glutinis DSM 70398, Rhodosporidium toruloides CBS 14, CBS 350, CBS 5490 and CBS 5475, Serratia marcescens ATCC 17999 and Streptococcus sobrinus ATCC 33478. S. sobrinus strains $6715-$ T2 and B-13 were

gratefully given by Dr. R. Linzer (Buffalo, U.S.A.). The isolation, screening, and maintenance procedure of the unknown strains are shown in Table 1. All culture media are described in Table 2.

The strains were isolated at $30^{\circ} \mathrm{C}$ after incubation of samples for 3 to 28 days. Attempts to isolate microorganisms at $3 \mathrm{rc}$ and $55^{\circ} \mathrm{C}$ and to isolate yeasts on malt agar (Difco) were abandoned because they led to a small number of poorly growing strains.

Determination of the $6 \mathrm{dh}$. The amounts of $6 \mathrm{dh}$ produced by the strains were determined after culture for 2 days in medium $\mathrm{K} 1$ or after culture for 3 days on medium BA (Table 2). The collec tion strains of Beijerinckia were cultured on the Beijerinckia medium recommended by the DSM, and the S. sobrinus strains were cultured on complemented Todd-Hewitt agar (Difco) (Prakobphol and Linzer, 1980). The 6dh produced were assayed by the sulfuric acidcystein method for methyl pentoses using L-rhamnose as the standard (Dische and Shettles, 1948). The assays were carried out on'the 1:10 diluted culture medium K1 or on buffered saline suspensions of colonies grown on BA. Results obtained were compared to the amount 
of $6 \mathrm{dh}$ produced by Acinetobacter calcoaceticus BD 413 (A. calcoaceticus) cultured under conditions similar to the tested strains.

\section{Identification of the $6 \mathrm{dh}$ produced by thin-layer-chromatography (TLC).}

Strains producing more $6 \mathrm{dh}$ than A. calcoaceticus were cultured in medium B (Table 2) for 3 days. One $\mathrm{ml}$ of each culture was mixed with $4 \mathrm{ml}$ of cold acetone and stirred for $30 \mathrm{~min}$ at $4^{\circ} \mathrm{C}$. The precipitate obtained was dried at $60^{\circ} \mathrm{C}$, suspended in one $\mathrm{ml}$ of $2 \mathrm{~N} \mathrm{H} 2 \mathrm{~S} 04$, hydrolyzed for $2 \mathrm{~h}$ at $100^{\circ} \mathrm{C}$, neutralised with $\mathrm{NaOH}$ and freeze-dried. The dried samples were resuspended in ethanol and qualitative analysis of sugars was performed by TLC (Randerath, 1971). Aliquots of 25 1-l1 were spotted on Kieselgel 60 plates and eluted with butanol: acetone: water (4:5:1). The plates were sprayed with a solution containing 10 parts of a $0.2 \%$ methanolic dihydroxy-I,3 naphtalene and 1 part of phosphoric acid $85 \%$. Blue to purple spots appeared after heating at $100-110^{\circ} \mathrm{C}$ for $5-10 \mathrm{~min}$.

\section{Determination of cell-bound and extracellular $6 \mathrm{dh}$.}

Strains producing more $6 \mathrm{dh}$ than A. calcoaceticus were cultured in $100 \mathrm{ml}$ flasks containing $20 \mathrm{ml}$ of medium $\mathrm{Kl}$ for 5 days at $30^{\circ} \mathrm{C}$ and at $150 \mathrm{rpm}$. The media were inoculated with one $\mathrm{ml}$ of a bacterial suspension spectrophotometrically standardized at an absorbancy of 0.15 (545 nm). Following incubation, $10 \mathrm{ml}$ culture samples were centrifuged for $20 \mathrm{~min}$ at 12000 $\mathrm{x} \mathrm{g}$ and at $4^{\circ} \mathrm{C}$. The wet cell pellets were weighed and resuspended in $10 \mathrm{ml}$ of sodium phosphate buffer $0.1 \mathrm{M}$ at $\mathrm{pH}$ 7.0. The amount of cell-associated

$6 \mathrm{dh}$ (whole cell suspensions), extracellular 6dh (supernatant) and total 6dh (culture medium) were determined by the method of Dische and Shettles (1948).

\section{Culture medium and growth conditions of Klebsiella sp (strain 82).}

The culture medium K4 (Table 2) for growing Klebsiella sp.(strain 82) was derived from experiments described in "Results". The effect of aeration on the growth and the 6dh production was studied in 21 fermentors (Biolafitte) containing 11 of medium K4 at $30^{\circ} \mathrm{C}$.

Isolation of the polysaccharides and of the rhamnose produced by Klebsiella sp (strain 82).

Klebsiella sp. (strain 82) was cultured for 5 days at $30^{\circ} \mathrm{C}$ and at $100 \mathrm{rpm}$ in a 21 flask with 4 baffles containing $250 \mathrm{ml}$ of the medium K4. Following incubation, the culture was autoclaved at $120^{\circ} \mathrm{C}$ for $20 \mathrm{~min}$ prior to centrifugation at $4^{\circ} \mathrm{C}$ and $12000 \mathrm{xg}$ or $10 \mathrm{~min}$. The supernatant was precipitated with one volume of cold acetone and the precipitate recovered by centrifugation at $4^{\circ} \mathrm{C}$ and $12000 \times \mathrm{g}$ for $10 \mathrm{~min}$.

The polysaccharides were hydrolyzed with $2 \mathrm{~N} \mathrm{H} 2 \mathrm{SO} 04$ at $100^{\circ} \mathrm{C}$ for $6 \mathrm{~h}$, neutralized with $\mathrm{NaOH}$ and freeze-dried. Samples from the dried polysaccharides were resuspended in the equilibration buffer of the column used to separate the individual sugars from the hydrolysate. A $40 \times 1.5$ em column filled with the resin Dowex $1 \times 4$ pratical grade $(\mathrm{OH}-)$ equilibrated with borate buffer $(0.11 \mathrm{M}$ sodium tetraborate and $0.17 \mathrm{M}$ boric acid, $\mathrm{pH} 8.8$ ) 
was used according to the method of Floridi (1971). Prior to chromatography, the resin was washed with $2 \mathrm{~N} \mathrm{NaOH}$ followed by water, then with $0.5 \mathrm{M}$ boric acid followed by water and finally with the equilibration buffer. A sample of one $\mathrm{ml}$ was applied to the column eluted at $25^{\circ} \mathrm{C}$ with the equ libration buffer at a rate of $1 \mathrm{ml} \mathrm{min-i.} \mathrm{Four} \mathrm{ml}$ fractions were collected and assayed for their hexose content by the anthrone method.

Components of the different peaks obtained were identified by TLC by comparison with sugar references.

\section{Results}

Screening

Selection of strains producing more 6dh than A. calcoaceticus.

Thirteen strains listed at the bottom of Table 3 were found to produce more $6 \mathrm{dh}$ than $A$. calcoaceticus when cultured in $20 \mathrm{ml}$ of medium $\mathrm{K} 1$. Most of these strains were isolated from sewage sludge. No soil isolate produced $6 \mathrm{dh}$ while only two out of 27 collection strains described as containing $6 \mathrm{dh}$ were found positive in this respect.

Identification of $6 d h$ produced by TLC. Among the strains producing more $6 \mathrm{dh}$ than $A$. calcoaceticus, strains producing a rhamnose-containing polysaccharide were: Beijerinckia mobilis NCIB 9879 and DSM 1720, strains 82 (identified as Klebsiella sp.), 92, 93, 97, 105. Strain 134 produced a fucose-containing polysaccharide. Strain 64 produced rhamnose- and fucose-containing polysaccharide.

6 dh produced by strains $110,141,143,144$ could not be determined clearly by TLC.

\section{Determination of total, cell-bound and extracellular 6dh.}

Among the 13 strains selected as producing more $6 \mathrm{dh}$ than $A$. calcoaceticus, four were discarded (nO 97, 110, 143 and Beijerinckia mobilis DSM 1720) since they did not reach the same level of $6 \mathrm{dh}$ production as $A$. calcoaceticus, when subcultured. Nine strains produced more $6 \mathrm{dh}$ than $A$. calcoaceticus (Table 4). The strain 82 (Klebsiella sp.) was selected for further investigation. The medium $\mathrm{KI}$ promoted a better growth of the strains isolated in medium $\mathrm{H}$ (strains 93, 134, 141, 144) than the medium $\mathrm{H}$ itself. Nevertheless growth of these strains in medium $\mathrm{KI}$ was low. For unexplained reasons, $6 \mathrm{dh}$ assayed in the supernatant and in the pellet suspension were very low for strains 134, 14i, 144.

Parameters of components influencing the production of rhamnose by Klebsiella sp. (strain 82)

Mannitol or sorbitol and L-phenylalanine promoted the production of the rhamnosecontaining polysaccharide (Table 5). Two phosphate concentrations (media K2 and K3) were 
tested. The lower concentration promoted a higher production of rhamnose. The different parameters or components listed in Table 6 were found to enhance the production of rhamnose by Klebsiella sp. (strain 82).

Neither the stationary phase of growth nor the maximum production of the polysaccharide from Klebsiella sp. (strain 82) were reached when grown in an aerated fermentor after 5 incubation days (Fig. 1). In a non-aerated fermentor both maximum growth and polysaccharide production were reached after the third incubation day. Al- though growth was much more important in the non-aerated fermentor, rhamnose production was much lower than in the aerated fermentor.

Isolation of the polysaccharide and of the rhamnose produced by Klebsiella sp. (strain 82)

The culture supernatant (medium K4) used for the isolation of the polysaccharide of Klebsiella sp. (strain 82 ) con- tained 1.6 gil of rhamnose. $90 \%$ of the polysaccharide was precipitated by one volume of acetone or two volumes of ethanol. The polysaccharide was not precipitated with cetylpyridinium chlorure concentration up to $17 \%(\mathrm{w} / \mathrm{v})$, and it was not adsorbed to chomatographic supports such as eM - or DEAE-Sepharose (Pharmacia). These two last results suggest that the polysaccharide is neutral. Following precipitation of the polysaccharide by acetone, hydrolysis, neutralization and freeze-drying, the monosaccharides were separated as borate-sugar complexes by chromatography on Dowex $1 \times 4$. The sugar components of the polysaccharide of Klebsiella sp. (strain 82) were identified as rhamnose and glucose by TLC. The presence of glucose was also confirmed by the enzymatic analysis of the hydrolysate using the YSI glucose analyser (YSI model $23 \mathrm{~A}$ glucose analyser).

\section{Discussion}

Rhamnose and fucose are 6-deoxyhexoses (6dh) which can be used as starting material by the flavouring industry.

The purpose of our work was to find screening and culture conditions leading to the isolation of microorganisms producing 6dh-containing polysaccharides. We did not isolate any microorganisms excreting free rhamnose or free fucose in the culture medium. We confirmed the presence of microorganisms producing $6 \mathrm{dh}$-containing polysaccharides in sewage sludges (Kakii et al., 1986; Rideau and Morfaux, 1976) since nine strains, out of thirteen positive strains, were selected from sludge samples, in particular strain 82 (Klebsiella sl.) producing much more $6 \mathrm{dh}$ than the other isolates. Hydrocarbons effectively favour the development of polysaccharide-producing strains (Guerra Santos, 1985) since the most efficient isolation culture medium was medium $\mathrm{H}$ containing hexadecane. 
The assay of the $6 \mathrm{dh}$ produced using the method of Dische and Shettles (1948) was efficient since it permitted to detect the 6dh-producing strains and to quantify the production of $6 \mathrm{dh}$ in defined culture media. The choice of the culture media used for the determination of the $6 \mathrm{dh}$ produced was based on their ability to permit sufficient growth of all strains while not interfering with the $6 \mathrm{dh}$ assay. Moreover liquid media were prefered to solid ones, since it was impossible to assay the $6 \mathrm{dh}$ of a microbial colony taken with its agar support as agar interfered with the assay. The colonies of a strain grown on a solid medium had thus to be suspended in saline before the $6 \mathrm{dh}$ assay. If some polysaccharides had diffused in agar, they consequently escaped the assay. 6dh production of strains selected in medium $\mathrm{H}$ and collection strains was nevertheless estimated after culture in medium $B$, which interferes with the $6 \mathrm{dh}$ assay, a $\$$ these strains had a sufficient growth only in medium $B$.

The present screening permitted the selection of 13 strains producing more $6 \mathrm{dh}$ than $A$. calcoaceticus. It is known that a number of cultural conditions such as the concentration and source of carbon, nitrogen, phosphorous, aeration, temperature and $\mathrm{pH}$, determine the production of polysaccharides (Sutherland, 1972; 1977; Troy II, 1979). Furthermore, the sources of carbon are likely to modify the sugar composition of polysaccharides (Bryan et al., 1986; Kaplan and Rosenberg, 1982). The improvement of the composition of the Klebsiella $\mathrm{sp}$. (strain 82 ) culture medium led to medium $\mathrm{K} 4$ having a carbon/nitrogen ratio close to 70 , and resulting in a $6 \mathrm{dh}$ production of $1.6 \mathrm{~g} . \mathrm{l}-1 \cdot$

The number of techniques available to achieve recovery and purification of microbial polysaccharides is large and the methods used depend on the strain studied (Aspinall, 1982). The recovery of the polysaccharide from Klebsiella sp. (strain 82) $45 \%$ of which appeared to be cell-associated, was performed using simple methods such as autoclaving and centrifugation. Following solvent precipitation and acid hydrolysis, the separation of the borate-sugar complexes on Dowex $1 \times 4$ was successful in that rhamnose was clearly separated.

Optimization of the culture conditions and of the recovery of the 6dh-containing polysaccharide and the recourse to genetic modification could further enhance the yield of $6 \mathrm{dh}$ obtained from Klebsiella sp. (strain 82).

Acknowledgments. The useful advice of Dr. F. Duchiron (BioEurope) in the course of this work is gratefully acknowledged.

We thank Dr. G. Wagener (Instirut Pasteur, Paris, France) for the identification of strain 82 (Klebsiella sp.).

References 
1. Aspinall, G. 0.: Isolation and fractionation of polysaccharides. In: The polysaccharides (G. O. Aspinall, ed.), Vol.

1, pp. 19-34. London, Academic Press Inc. 1982

2. Berthelet, D., Michel,\}. P., Heyraud, A., Rinaudo, M.: Rapport bibliographique. Vol. 1: Rapport du CERMAV pour le ministere de l'industrie et de la recherche dans le cadre du programme mobilisateur "Essor des biotechnologies". Avril 1984

3. Bryan, B. A., Linhardt, R. J., Daniels, L.: Variation in composition and yield of exopolysaccharides produced by Klebsiella sp. strain K32 and Acinetobacter calcoaceticus BD4. Appl. Environ. Microbiol. 51, 1304-1308 (1986)

4. Dische, Z., Shettles, L. B.: A specific color reaction of methyl-pentoses and a spectrophotometric micromethod for their determination. J. Biol. Chern. 175, 595-603(1948)

5. Floridi, A.: An improved method for the automated analysis of sugars by ion-exchange chromatography. J. Chromatogr. 59, 61-70 (1971)

6. Guerra Santos, L. H. Physiology of Pseudomonas aeruginosa biosurfactants production in continuous culture. Dissertation ETH No. 7722. Zurich, Swiss Federal Institute of Technology 1985

7. Kakii, K., Shirakashi, R., Kuriyama, M.: Some properties of mucilage polysaccharides extracted from sewage activated sludge. J. Ferment. Technol. 62, 429-435 (1986)

8. Kaplan, N., Rosenberg, E.: Exopolysaccharide distribution and bioemulsifier production by Acinetobacter calcoaceticus BD4 and BD413. Appl. Environ. Microbiol. 44, 1335-1341 (1982)

9. Lawson, C. L., Sutherland, I. W.: Polysaccharides. In: A. H. Rose Economic Microbiology, Vol. 2, pp. 327-392. London, Academic Press 1978

10. Martin, D. R.: Mucoid variation in Pseudomonas aeruginosa induced by the action of phage. J. Med. Microbiol. 6, 111-118 (1973) 11. Paul, F., Morin, A., Monsan, P. F.: Microbial polysaccharides with actual potential industrial applications. Biotechn. Advanc 4, 245-259 (1986)

12. Prakobphol, A., Linzer, R.: Purification and immunological characterization of rhamnoseglucose antigen from Streptococcus mutans 6715-T2 (serotype g). Infect. Immun. 30, 140146(1980)

13. Randerath, K.: Chromatographie sur couches minces, 2ieme ed. Paris, Gauthiers-Villars 1971

14. Rideau, J. P., Morfaux, J. N.: Etude des polyosides du mucilage des boues activees. Water Res. 10, 999-1003 (1976)

15. Rubinovitz, c., Gutnick, D. L., Rosenberg, R.: Emulsan production by Acinetobacter calcoaceticus in the presence of chloramphenicol. J. Bact. 152, 126-132 (1982)

16. Sutherland, 1. W.: Bacterial exopolysaccharides. Advanc. Microbiol. Physiol. 8, 143-213 (1972)

17. Sutherland, 1. W.: Bacterial exopolysaccharides, their nature and production. In: Surface carbohydrates of the prokaryotic cell (1. W. Sutherland, ed.), pp. 27-96. New York, Academic Press Inc. 1977

18. Troy II, F. A.: The chemistry and biosynthesis of selected bacterial capsular polymers. Ann. Rev. Microbiol. 33, 519-560 (1979) 
19. Voelskow, H., Schlingmann, M.: Process for the production of rhamnose or fucose. German Pat. DE 3, 300, 633, 1984

20. Wang, X. Y., Schwartz, W.: Conditions of the exopolysaccharide synthesis from nhexadecane by an oil-positive bacterium 437. J. Basic Microbiol. 25, 213-219 (1985)

Table 1. Isolation, screening and maintenance procedure

\begin{tabular}{lllll}
\hline $\begin{array}{l}\text { Source of } \\
\text { microorganisms }\end{array}$ & Abbreviations & $\begin{array}{l}\text { Isolation } \\
\text { medium }^{\mathrm{a}}\end{array}$ & $\begin{array}{l}\text { Screening } \\
\text { medium }^{\mathrm{a}}\end{array}$ & $\begin{array}{l}\text { Maintenance } \\
\text { medium }^{\mathrm{a}}\end{array}$ \\
\hline $\begin{array}{l}\text { Collection } \\
\text { strains }\end{array}$ & $\begin{array}{l}\text { ATCC, DSM, IP, None } \\
\text { NCIP, CBS }\end{array}$ & $\begin{array}{l}\text { BA or special } \\
\text { media }\end{array}$ & $\begin{array}{l}\text { BA or special } \\
\text { media }\end{array}$ \\
\hline
\end{tabular}

Isolates from:

Humic soil

Dung

$\left.\begin{array}{l}\mathrm{S} \\ \mathrm{D}\end{array}\right\}$

$\mathrm{H}, \mathrm{HA}$

BA

Oily deposits

$\mathrm{O}$

$\mathrm{H}$

$\mathrm{BA}$

Sewage sludge ${ }^{\mathrm{a}}$

Cla S

(Clarification)

Sewage sludge

(Stabilization)

Sewage sludge

Sta S

(Recycling)

Dried sludge

RS

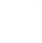

DS

RA, BA K1

Strains isolated on medium $\mathrm{H}$

BA were screened on medium BA and strains isolated on media RA and $\mathrm{BA}$ were screened on medium $\mathrm{K} 1$.

a The final $\mathrm{pH}$ of all media was $7.0 \pm 0.1$ after sterilization.

$b$ The sewage sludge samples were taken from the wastewater treatment plant of Ramonville St-Agne (Toulouse, France).

Table 2. Composition of the culture media in $\mathrm{g} . \mathrm{l}^{-1}$ 


\begin{tabular}{|c|c|c|c|c|c|c|c|}
\hline \multirow[t]{2}{*}{ Component } & \multicolumn{7}{|c|}{ media } \\
\hline & $\mathrm{H}$ & $\mathrm{R}$ & B & $\mathrm{K} 1$ & K2 & K3 & K4 \\
\hline $\mathrm{K}_{2} \mathrm{HPO}_{4}$ & 3.0 & 3.0 & - & 3.0 & 9.0 & 22.0 & 9.0 \\
\hline $\mathrm{KH}_{2} \mathrm{PO}_{4}$ & 1.5 & 1.5 & - & 1.5 & 3.0 & 7.0 & 3.0 \\
\hline$\left(\mathrm{NH}_{4}\right)_{2} \mathrm{SO}_{4}$ & 1.0 & 1.0 & - & 1.0 & 1.0 & 1.0 & - \\
\hline $\mathrm{MgSO}_{4}$ & 5.5 & 5.5 & - & 5.5 & 5.5 & 5.5 & 0.2 \\
\hline $\mathrm{KCl}$ & 0.3 & 0.3 & - & - & - & - & - \\
\hline $\mathrm{NaNO}_{3}$ & 1.5 & 1.5 & - & - & - & - & - \\
\hline $\mathrm{CaCl}_{2}$ & 0.03 & 0.03 & - & - & - & - & - \\
\hline $\mathrm{FeCl}_{3}$ & 0.002 & 0.002 & - & - & - & - & - \\
\hline $\mathrm{MnSO}_{4}$ & 0.002 & 0.002 & - & 0.002 & .002 & .002 & - \\
\hline $\mathrm{H}_{3} \mathrm{BO}_{3}$ & 0.0004 & 0.0004 & - & 0.0004 & .0004 & .0004 & - \\
\hline $\mathrm{CoCl}_{2}$ & 0.0002 & 0.0002 & - & 0.0002 & .0002 & .0002 & - \\
\hline $\mathrm{CuSO}_{4}$ & 0.0002 & 0.0002 & - & 0.0002 & .0002 & .0002 & - \\
\hline Yeast extract & 0.02 & 0.02 & - & 0.02 & .02 & .02 & .02 \\
\hline Hexadecane & 25.0 & - & - & - & - & - & - \\
\hline Rhamnose & - & 10.0 & - & - & - & - & - \\
\hline Brain heart infusion & - & - & 37 & - & - & - & - \\
\hline Glucose & - & - & 40.0 & 4.0 & - & - & - \\
\hline Mannitol or Sorbitol & - & - & - & - & 10 & 10 & 10 \\
\hline Phenylalanine & - & - & - & - & 1 & 1 & 1 \\
\hline Tween 80 & - & - & - & - & 1 & 1 & 1 \\
\hline
\end{tabular}

a When these media were used as solid media, agar $2 \%\left({ }^{\mathrm{w}} / \mathrm{v}\right)$ was added. Media with agar were named HA, RA, BA.

Table 3. Number of strains producing more $6 \mathrm{dh}$ than A. calcoaceticus / Number of strains isolated 


\begin{tabular}{|c|c|c|c|c|c|c|c|c|}
\hline \multirow[b]{2}{*}{$\begin{array}{l}\text { Isolation medium } \\
\text { (incubation time) }\end{array}$} & \multirow[b]{2}{*}{ Collections $^{b}$} & \multirow[b]{2}{*}{$S$} & \multicolumn{5}{|c|}{ Source of microorganisms $\mathrm{s}^{\mathrm{a}}$} & \multirow[b]{2}{*}{ DS } \\
\hline & & & $\mathrm{D}$ & $\mathrm{O}$ & $\mathrm{Cla} \mathrm{S}$ & Sta $S$ & RS & \\
\hline \multirow{4}{*}{$\begin{array}{l}\mathrm{HA},(3 \text { days }) \\
\mathrm{H},(0-1 \text { week }) \\
\mathrm{H},(1-2 \text { weeks }) \\
\mathrm{H},(2-4 \text { weeks })\end{array}$} & \multirow{6}{*}{$\begin{array}{l}\text { No } \\
\text { isolation } \\
\text { necessary }\end{array}$} & $0 / 9$ & $0 / 12$ & - & - & - & - & - \\
\hline & & $0 / 7$ & $0 / 7$ & $0 / 4$ & $0 / 3$ & - & $0 / 4$ & $0 / 2$ \\
\hline & & $0 / 8$ & $0 / 4$ & - & - & - & - & - \\
\hline & & $0 / 4$ & $1 / 4$ & $1 / 3$ & $1 / 4$ & $2 / 3$ & $0 / 3$ & $0 / 2$ \\
\hline \multirow{2}{*}{$\begin{array}{l}\text { RA, (3 days) } \\
\text { BA, (3 days) }\end{array}$} & & - & - & $0 / 5$ & $1 / 6$ & $0 / 2$ & $1 / 5$ & $1 / 5$ \\
\hline & & - & - & $0 / 7$ & $0 / 3$ & $1 / 11$ & $1 / 4$ & $1 / 4$ \\
\hline $\begin{array}{l}\text { Total of positive } \\
\text { strains }^{c}\end{array}$ & $2 / 27$ & $0 / 28$ & $1 / 27$ & $1 / 19$ & $2 / 16$ & $3 / 16$ & $2 / 16$ & $\begin{array}{l}2 / 13 \\
13 / 162\end{array}$ \\
\hline \multirow{3}{*}{$\begin{array}{l}\text { Strains } \\
\text { number }\end{array}$} & \multirow{3}{*}{$\begin{array}{l}\text { B. mobilis } \\
\text { NCIB } 9879 \\
\text { and DSM } 1720\end{array}$} & \multirow[t]{3}{*}{-} & \multirow[t]{3}{*}{110} & \multirow[t]{3}{*}{144} & 97 & 93 & 82 & 64 \\
\hline & & & & & 134 & 141 & 105 & 92 \\
\hline & & & & & & 143 & & \\
\hline
\end{tabular}

a See Table 1 for the meaning of the abbreviations.

${ }^{b}$ Collection strains: ATCC, DSM, NCIB, IP, CBS, Private Collection, see "Materials and Methods".

c A positive strain produced more $6 \mathrm{dh}$ than the reference strain A.calcoaceticus.

Table 4. Strains producing more $6 \mathrm{dh}$ than $A$. calcoaceticus and excreting more than $50 \%$ of the 6dh-containing polysaccharide

\begin{tabular}{lll}
\hline Strain & A & B \\
\hline A.calcoaceticus & 80 & 88 \\
B.mobilis NCIB 9879 & 95 & 71 \\
64 & 96 & 83 \\
82 (Klebsiella sp.) & 842 & 55 \\
92 & 102 & 87 \\
93 & 104 & 65 \\
105 & 265 & 54 \\
134 & 128 & - \\
141 & 158 & - \\
144 & 190 & - \\
\hline
\end{tabular}

$\mathrm{A}=6 \mathrm{dh}$ concentration in the culture medium $\left(\mathrm{mg} \cdot \mathrm{1}^{-}\right)$.

$B=\%$ of extracellular polysaccharide. 
Table 5. Effect of carbon and nitrogen source on the production of the rhamnose-containing polysaccharide by Klebsiella sp. (strain 82)

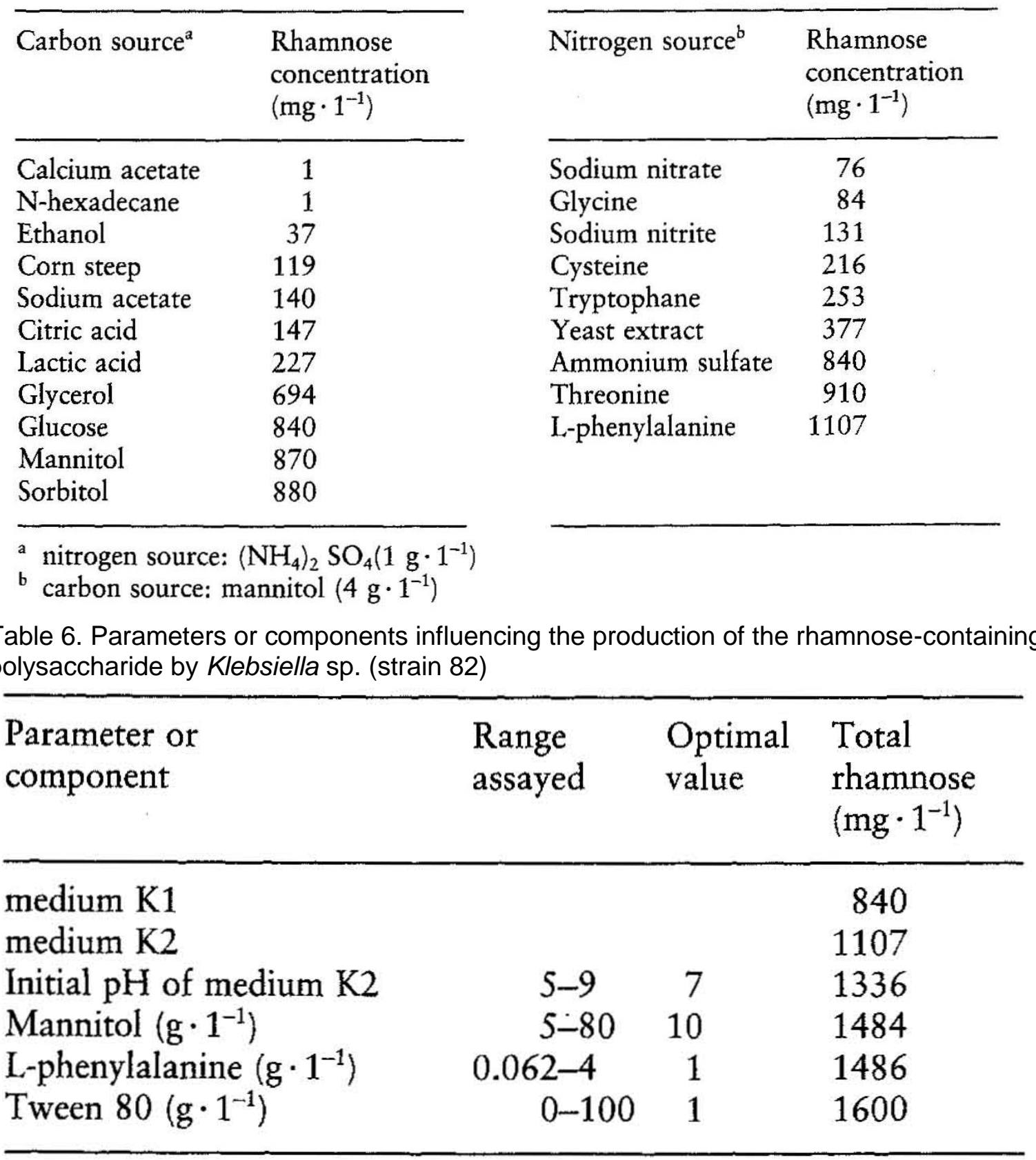


Fig. 1. Growth and production of the rhamnose-containing polysaccharide by Klebsiella sp. (strain 82) in aerated (0) and non aerated $\left(^{*}\right) 2$ I fermentor. ( ... = absorbance at $545 \mathrm{~nm} ;$ - = total rhamnose)

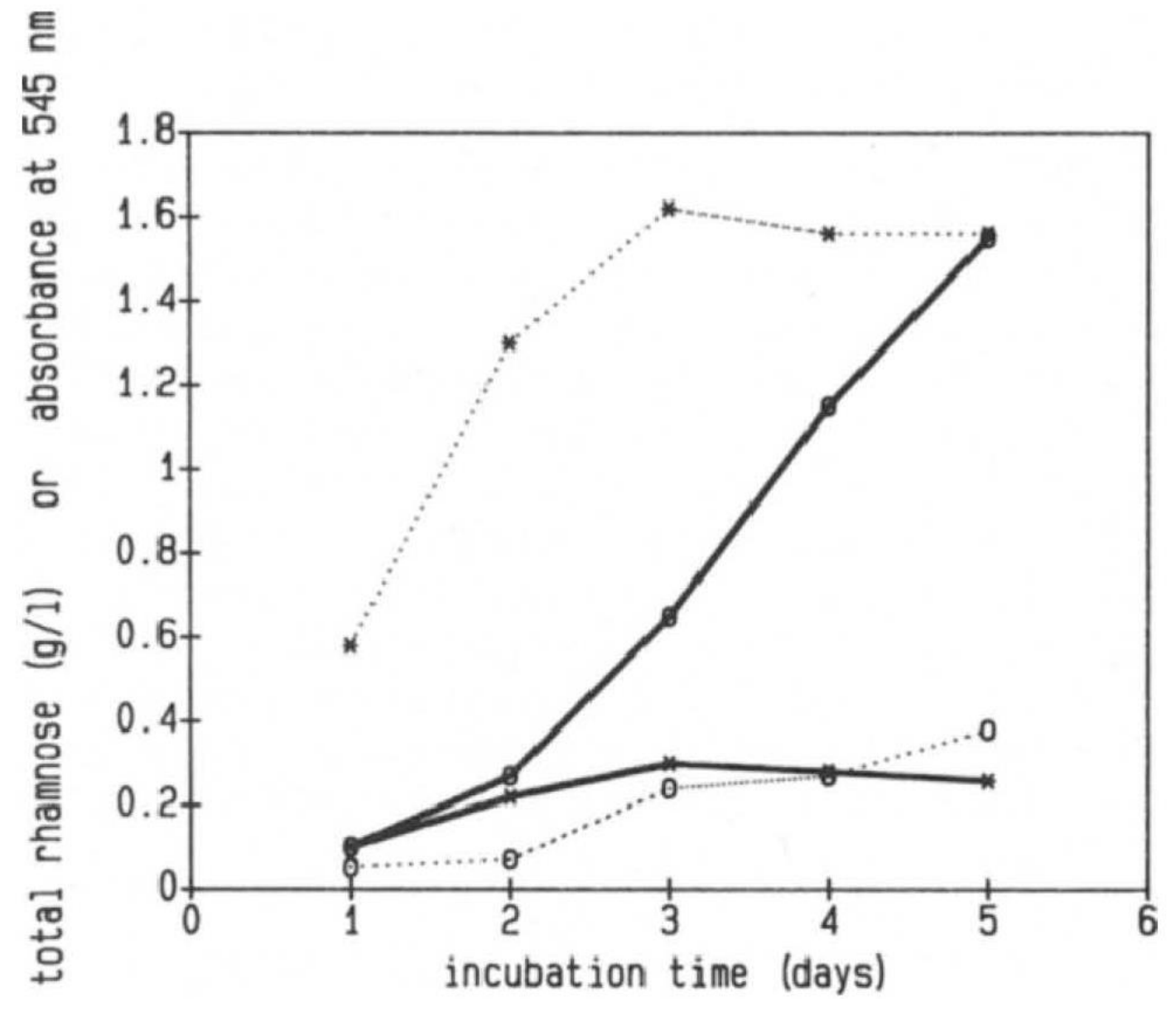

